\title{
Development of managerial and Information Technology skills in Learning Factories in the context of Industry 4.0: a case study
}

Pedro Antonio de Albuquerque Felizola Romeral ${ }^{1}$, University of São Paulo, São Paulo, Brazil

Mauro de Mesquita Spinola², University of São Paulo, São Paulo, Brazil

Rodrigo Franco Gonçalves ${ }^{3}$, University of São Paulo, São Paulo, Brazil

Eduardo de Senzi Zancul ${ }^{4}$, University of São Paulo, São Paulo, Brazil

\section{RESUMO}

Objetivo - Esta pesquisa tem como objetivos: analisar quais são as tecnologias mais relevantes e presentes em Learning Factories; analisar como essas tecnologias se integram; e analisar como esse ambiente atua frente à escassez de mão de obra especializada.

Referencial teórico - O novo panorama tecnológico, representado pela Indústria 4.0, requer pessoal capacitado para operar, interpretar e tomar decisões frente às novas ferramentas. Nesse contexto, a formação de profissionais para atuar na manufatura precisa proporcionar contato com a arquitetura de Tecnologia da Informação (TI) atualizada e estimular o desenvolvimento de competências que permitam uma atuação eficaz. Uma forma de agir nessas frentes é por meio das Learning Factories, que são ambientes propícios para a capacitação perante a Indústria 4.0 e para o desenvolvimento de tecnologia, suas aplicações, e transferência para a indústria. Apesar do reconhecimento do valor dessa estratégia, não há uma discussão clara sobre como se constrói a arquitetura de TI, como se dá a integração das tecnologias e quais as estratégias didáticas eficazes nas Learning Factories.

Desenho/metodologia/abordagem - Foi realizado um estudo de caso de uma Learning Factory de uma universidade estadual brasileira, chamada Fábrica do Futuro, expondo os sistemas de informação presentes, sua relevância na formação dos estudantes e as estratégias didáticas já adotadas, comparando o caso com a fundamentação teórica apresentada.

Resultados - Foi identificada a necessidade de explorar a integração entre as tecnologias, envolvendo ferramentas como Impressão 3D, identificação por radiofrequência (RFID), Visão Computacional e sistemas como ERP, MES e PLM. Além disso, é preciso estimular o desenvolvimento de competências de comunicação, liderança e resolução de problemas para um eficaz aprendizado e boa operação dessas tecnologias.

Originalidade/Valor - Este trabalho visa contribuir com universidades e instituições de pesquisa que desejam implantar e/ou operacionalizar uma Learning Factory, apresentando e discutindo uma possível estrutura de TI e as competências desenvolvidas com a mesma.

Palavras-chave - Learning Factory. Indústria 4.0. Tecnologias de Informação. ERP. Impressão 3D.

\section{ABSTRACT}

Purpose - This paper aims to analyze the most relevant and present technologies in Learning Factories, to analyze how these technologies can be integrated and how to analyze how this environment operates given the shortage of a specialist workforce.

Theoretical framework - The new technological landscape, also known as Industry 4.0, requires trained personnel to operate, interpret, and make decisions given the new tools. This means that training the professionals who will work in the industries need to come into contact with all this existing Information Technology (IT) architecture and skills need to be encouraged to be developed to allow these professionals to work effectively. One way to act on these fronts is through Learning Factories, which are integrated environments for Industry 4.0 training and the development of technology, applications, and transfer them to industry. Despite recognizing this strategy, there is no explicit discussion on how IT architecture is built, how these technologies are integrated, and which teaching strategies are effective in Learning Factories.

Design/methodology/approach - A case study was carried out at a Learning Factory in a Brazilian state university, called 'Fábrica do Futuro', describing the present IT systems, their relevance in student education and the teaching strategies adopted, compared with the theoretical sample presented.

Findings - A need was identified to explore the integration between all technologies, involving tools, such as $3 D$ printing, radio frequency identification (RFID), Computer Vision and systems such as ERP, MES and PLM. The development of communication, leadership, and problem-solving skills needs to be encouraged for effective learning and adequate operation of these technologies.

Originality/Value - This study aims to contribute to universities and research institutions that wish to implant and/or operationalize a Learning Factory, presenting and discussing a possible IT structure and the skills developed with it.

Keywords - Learning Factory. Industry 4.0. Information Technologies. ERP. 3D printing.

1. Av. Professor Almeida Prado, 128, travessa, 2, Bairro Cidade Universitária, São Paulo - SP, Brasil, pedroromeral@usp.br; https://orcid.org/0000-0002-2619-6465; 2. $\quad$ mauro.spinola@usp.br, $\quad$ https://orcid.org/0000-0002-5147-9395; 3. rofranco212@gmail.com, https://orcid.org/0000-0003-2206-3136; 4. ezancul@usp.br, https://orcid.org/0000-0001-83610637.

ROMERAL, P.A.A.F.; SPINOLA, M.M.; GONÇALVES, R.F.; ZANCUL, E.S. Development of managerial and Information Technology skills in Learning Factories in the context of Industry 4.0: a case study. GEPROS. Gestão da Produção, Operações e Sistemas, v.16, $\mathrm{n}^{\circ}$ 2, p. 195 - 227, 2021.

DOI: http://dx.doi.org/10.15675/gepros.v16i2.2785 


\section{INTRODUCTION}

The rapid changes that the world is experiencing in the technological, economic, and societal sectors, due to globalization's influence, quickly modify the market conditions in which several companies operate (ADAMSON et al., 2017). This requires adapting companies and constantly seeking competitive advantages that lead to differentiation from their competitors (OLIVEIRA; SIMÕES, 2016). According to the German Ministry of Education and Research (2016), this scenario also implies the digitalization of society and the economy, building a panorama that merges the real and virtual worlds, significantly impacting industrial processes.

This new concept is characterized by Industry 4.0, which represents an era of increased digitalization and automation of industrial environments. The communication and the integration between processes are strengthened through digital value chains (OESTERREICH; TEUTEBERG, 2016). As a result, Industry 4.0 can be interpreted as a concept marked by the digitization and automation of processes and the intense application of Information Technologies (IT) in production operations (LU, 2017).

Within this technological context, Nakayama et al. (2020) point out some relevant tools that operate in the scope of Industry 4.0: Cloud Systems, Data Mining, Augmented Reality, and Virtual Reality. In addition, advanced systems such as Enterprise Resource Planning (ERP), Business Intelligence, and Autonomous Robots complement this complex spectrum.

For Picarozzi, Aquilani and Gatti (2018), Industry 4.0 is not just about technologies or production tools but something that implies changes in all aspects of management, whether internally or with partners in the production chain. This indicates that managers need to carefully formulate their transition strategy to Industry 4.0 considering several variables. Researchers should conduct more in-depth studies on these diverse topics in order to generate a support base for companies' analysis and decision making.

Beier et al. (2020) argue that, despite all the doubts inherent in the new industrial phase, companies' entry into the new scenario will positively change the existing forms of work and its relationships. The new technological tools coming from Industry 4.0 will require less physical effort but an increase in knowledge. If this trend is well explored, it will allow environments of greater creativity and incentive to new ideas. 
Among all the relevant aspects of Industry 4.0, it ensures that the workforce's qualification and the continuous improvement of related technologies are fundamental factors for the advancement of organizations. A survey carried out by the consulting firm McKinsey, in 2016, in organizations in Germany, the United States, and Japan sought to show the main barriers to implementation of Industry 4.0 cited by the companies interviewed. Among the main difficulties there is a lack of trained personnel, such as data scientists. Many manufacturers feel they lack the skills needed to make the new technologies in Industry 4.0 work properly. Besides, the new tools need to be better understood and adapted to the reality of each organization.

In this sense, competence is a relevant concept. It is worth reinforcing the definition adopted throughout the study, proposed by Fleury and Fleury (2001, p.188): "a responsible and recognized way to act, which implies mobilizing, integrating, transferring knowledge, resources, and skills, which add economic value to the organization and social value to the individual".

The link between Industry 4.0 technologies and people's skills is also relevant to conduct this study. The connections made in this sense are guided by the study of Salerno (1999), which presents the integration between technologies and people through the sociotechnical system.

Based on the previously discussed theoretical references, Pereira and Romero (2017) claim that Industry 4.0 is transforming jobs and necessary skills. The most significant change concerns the human-machine interface, which covers the interaction between workers and a set of new forms of collaborative work. Sung (2018) complements the idea by stating that it is necessary to accept that workers will need to acquire a new set of skills to adapt to the new industrial era. Therefore, for Nagy et al. (2018), the development and creation of jobs to allow companies to evolve in the Industry 4.0 scenario require training to create a digitally skilled workforce.

In this context, the new industrial paradigm will have a massive impact on the labor market and professional roles, and it is crucial to ensure that more jobs are created than disappear. The new required fields of competence need to be included in educational systems. Interdisciplinary thinking will play an important role, and social and technical skills will be needed. There will be greater automation of tasks, which means that workers must be prepared to carry out new activities. This must be reflected in engineering education, which 
has great potential to prepare professionals to the future and train them to act under new technological trends and opportunities. (PEREIRA; ROMERO, 2017)

The companies need to meet the requirements of Industry 4.0, through trained personnel, to deal with new technologies, and this needs to be addressed by universities and research institutes. Educational institutions are required to develop a didactic scenario in which the skills demanded by technology professionals can be developed. In this context, Learning Factories (LF) emerge as complex learning environments that allow the development of high-quality and autonomous skills, linked to the appropriate use of emerging Industry 4.0 technologies (BAENA et al., 2017).

Tisch et al. (2016) define Learning Factory as an idealized replica of industrial environments, where informal and formal learning takes place. The authors point out uses of these models of environments for educational, research, and training purposes, in areas such as manufacturing (Technical University of Darmstadt); energy efficiency (Green Factory Bavaria), and operations and service processes (McKinsey Capability Center Atlanta).

In Brazil, one of the initiatives that seek to improve the teaching of emerging technologies is found at a state university in São Paulo. The so-called Fábrica do Futuro project started in 2016 to implement a teaching environment with Industry 4.0 technologies that can be shared with several undergraduate and graduate courses. The main benefits are adopting effective teaching approaches in a modern and contextualized environment, contributing to increasing students' motivation and engagement.

Learning Factories have objectives that seek to aggregate the development of education, research, and disseminating knowledge in the industry. The results obtained in the students' activities bring greater awareness of the importance of Industry 4.0 among students and serve as an environment for the development and specific training of emerging technologies (ZANCUL et al., 2020).

Despite all the benefits, there is limited discussion about which technologies in Industry 4.0 deserve more attention (FRANK; DALENOGARE; AYALA, 2019) and the didactic strategies needed to prepare the industrial workforce for this new reality (ABELE $e t$ $a l ., 2019)$. Thus, it is important to analyze how Learning Factories support student learning, considering the most relevant technologies on the market within the context of Industry 4.0.

In the light of the previously discussed developments, the present study addresses the following research questions: 
Q1) How is the IT architecture of Learning Factories environments structured?

Q2) What aspects can be developed in a Learning Factory for industry professionals' technological education today?

This article aims to: 1) analyze which technologies are most relevant and present in Learning Factories, 2) analyze how these technologies are integrated, and 3) analyze how this environment acts in the face of a specialized labor shortage.

This article has the following structure. Section 2 "Theoretical Foundation" covers two main topics, each in its subsection: Industry 4.0 and Learning Factories; Section 3 "Methodology" describes the methodological process for carrying out this research through a case study; Section 4 "Case Study: Fábrica do Futuro" presents the studied case laboratory; Section 5 "Results" analyzes the field research data; Section 6 "Final Remarks" discusses the research's relevance and proposes a research agenda for future studies in the field.

\section{THEORETICAL FOUNDATION}

This section addresses the relevant topics associated with this study, such as Industry 4.0 and Learning Factories, discussed in the following subsections.

\subsection{Industry 4.0 - Definition, objectives, and technologies}

Each industrial era that humanity experienced has unique characteristics and presents technological advances that directly result in increased productivity (KAGERMANN et al., 2013). In the First Industrial Revolution, the emergence of steam engines replaced the predominant artisanal production model for fast, high-volume consumer goods production. In the Second Industrial Revolution, the introduction of electricity brought even greater volumes of production. The Third Industrial Revolution, also known as the "digital revolution", was marked by an increase in computing capacity through the invention of integrated circuits. This advance led to an era of information collection and management through the use of technologies (SCHUH et al., 2014; SABO, 2015).

Currently, we are experiencing a scenario of profound changes in the organizational structure of industries. For Posada et al. (2015), this is a renewal moment that explores and converges several emerging technologies. This new context characterizes the so-called Industry 4.0. According to Hermann et al. (2016), the term Industrie 4.0 (in German) was 
made public at a fair in Germany in 2011, where representatives of private and public institutions in the country promoted the initiative to strengthen the competitiveness of their industries. The German government soon announced recommendations and measures for the implementation of this new model at a national level.

It can be said that Industry 4.0 represents an increase in the digitization of processes and is marked by the use of Cyber-Physical Systems (CPS) for the generation of intelligent factories, whose tendency is to reduce human dependence on machine control (SANDERS et al., 2016). In addition, Industry 4.0 requires a socio-technical evolution of the human role in production systems, in which several jobs along the value chain will be based on Information Technologies (STOCK et al., 2018).

Baheti and Gill (2011) present the concept of Cyber-Physical Systems, which are innovative technologies that perform systems management where physical assets and computational resources are interconnected. The recent development of systems like these changes the competitive nature of industries, forcing them to plan their implementation in the processes. Lee et al. (2013) point out that the integration of CPS with production, logistics, and services in current industrial practices enhances the adoption of Industry 4.0 and represents significant economic potential.

To paraphrase Schwab (2016), Industry 4.0 can be seen as the product of a series of technologies inserted in the production processes. These technologies guide the way the processes will be modeled today. In this context, Rüßmann et al. (2015), in a booklet by the Boston Consulting Group, summarize nine enabling technologies that support the new Industrial Revolution, as shown in Table 1.

Table 1 - Main Industry 4.0 technologies and characteristics

\begin{tabular}{ll}
\hline \multicolumn{1}{c}{ Pilar } & \multicolumn{1}{c}{ Characteristics } \\
\hline Autonomous Robots & $\begin{array}{l}\text { Interact with other robots in the system, acting in conjunction with the } \\
\text { human operators and providing greater security. Over time, they will cost } \\
\text { less and provide a wider range of possibilities for action. }\end{array}$ \\
\hline Internet of Things (IoT) & $\begin{array}{l}\text { It allows communication between devices; decentralizes the control of } \\
\text { information and decision making. }\end{array}$ \\
\hline Big Data & $\begin{array}{l}\text { The effective collection and analysis of large amounts of data optimizes the } \\
\text { product's quality and supports real-time decisions. }\end{array}$ \\
\hline Simulation & $\begin{array}{l}\text { It brings the real world closer to the virtual, allowing testing of the industry's } \\
\text { most diverse aspects without changing the physical space and offering } \\
\text { important information such as setup time and quality. }\end{array}$ \\
\hline $\begin{array}{l}\text { Horizontal and } \\
\text { integration }\end{array}$ & vertical \\
\hline
\end{tabular}




\begin{tabular}{ll}
\hline & processes. \\
\hline Cloud & $\begin{array}{l}\text { Allows increased data storage volume, greater information sharing between } \\
\text { companies, and reduced response time. }\end{array}$ \\
\hline Cybersecurity & $\begin{array}{l}\text { Results in the protection of critical industry systems. It offers safe and } \\
\text { reliable conditions for accessing machines and obtaining information. }\end{array}$ \\
\hline Augmented Reality & $\begin{array}{l}\text { It allows the generation of information in real-time and better visualization } \\
\text { of processes. Thus, there is the possibility of effective virtual training. }\end{array}$ \\
\hline Additive Manufacturing & $\begin{array}{l}\text { It allows the elaboration of customized batches in low production volumes, } \\
\text { whose products may have complex geometry. 3D printing, for example, } \\
\text { facilitates the generation of prototypes. }\end{array}$ \\
\hline
\end{tabular}

Source: Rüßmann et al. (2015).

Autonomous robots are one of the great proposals of this new industrial era, but it is not well known how it will impact work environments. For Pereira and Romero (2017), the increasing adoption of robots will increase the relevance of human-machine interfaces and factory equipment integration. It is not enough for the equipment to be innovative if it does not consider ergonomic issues, and that is why the authors argue that future systems should also focus on workers and their role.

$\mathrm{Xu}, \mathrm{Xu}$ and $\mathrm{Li}$ (2018) point out, within the Internet of Things, the relevance of radio frequency identification (RFID) technology. By connecting the RFID reader to the Internet, readers can automatically and exclusively identify and track objects with attached tags in realtime. Therefore, users can automatically distinguish, track and monitor any object marked with RFID tags. Learning how to use these technologies helps to accelerate storage and production control processes.

Another technology worth mentioning for $\mathrm{Xu}, \mathrm{Xu}$ and $\mathrm{Li}$ (2018) is cloud computing, as it offers high performance and low cost. It allows resource sharing, dynamic allocation, flexible extension, and numerous other advantages. A large amount of data can be loaded into a cloud computing center for storage and analysis, facilitating manufacturing and production.

In view of the whole scenario, $\mathrm{Lu}$ (2017) summarizes the objectives of Industry 4.0: provide mass customization enabled by IT; make an automatic and flexible adaptation of the production chain; track parts and products; facilitate communication between parts, products, and machines; achieve optimization of production enabled for the Internet of Things (IoT) in smart factories; and provide new types of services and business models for interaction in the value chain.

It is worth mentioning that Industry 4.0 is not just a discussion about technologies. Aspects related to business and people management are relevant and also deserve to be 
highlighted. According to Picarozzi, Aquilani and Gatti (2018), there are few works on Industry 4.0 oriented to the managerial and business aspects of this new industrial phase or that deal with innovation caused by the adoption of new technologies. Therefore, there are fields to be explored and developed, and uncertainties come to this point.

In the business aspect, Industry 4.0 seeks to solve the following demands: production on demand, or customization, which may include even single production batches, reduction in product development time as a result of competition; flexibility in product development and production; decentralization for more agile decision making, reducing hierarchies; and even resource efficiency and sustainability issues (LASI et al., 2014).

In the field of people management, there is the objective of preparing skilled workers to work in modern processes. It is necessary to develop creativity, systemic vision, and other competencies necessary for organizations to perform their tasks in an agile and effective way. In addition, Industry 4.0 has the power to modify the working relationships we know nowadays, and the challenge is to propose new models that avoid negative impacts on society: flexible working hours, online work, etc. (SIMA et al., 2020).

The main objectives of Industry 4.0 can be summarized in Table 2.

Table 2 - Summary of the main objectives of Industry 4.0

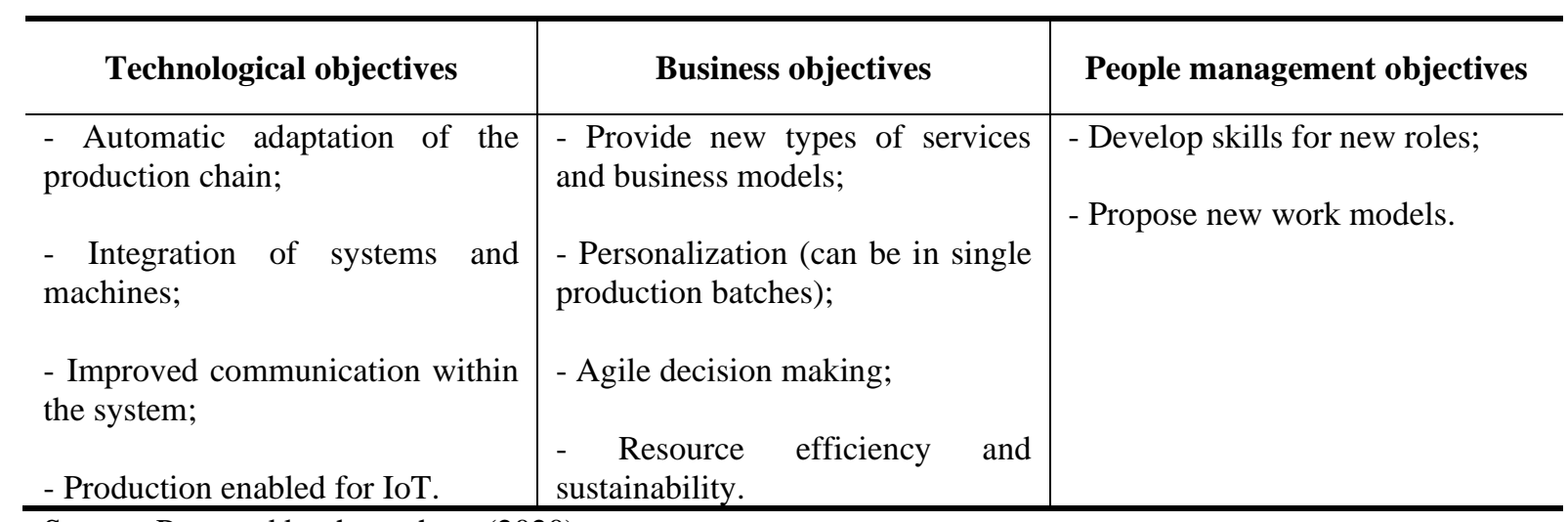

Source: Prepared by the authors (2020).

Celaschi (2017) analyzed Industry 4.0, placing the human being a central role and evaluating how technologies interfere in this process. Besides, the author provided important insights on which technologies can help achieve specific business objectives, as shown in Table 3. 
Table 3 - Relationship between objectives and technologies that enable processes

\begin{tabular}{cc}
\hline Objectives & Technologies \\
\hline Speed & CAD 2D e 3D \\
Cost reduction & 3D printing \\
Customized lots & Simulation \\
\hline Reliability & Cloud \\
Quality & IIoT \\
Customization & Simulation \\
Increased supply chain connection & Diversified sensors \\
\hline & IIoT \\
Predictive maintenance & Diversified sensors \\
Servitization & Big Data and Analytics \\
& Augmented Reality \\
& GPS \\
Disruptive innovation & Diversified sensors \\
Anticipation (predictions) & Big Data and Analytics \\
& Digital Modeling \\
& 3D Printing \\
\hline
\end{tabular}

Source: Celaschi (2017).

It appears that a strong technological discussion prevails, and it does not necessarily point to converging paths. In addition, there is a lack of detailed research on how to promote the training of those involved in the face of these new Information Technologies. This is in line with Oesterreich and Teuteberg (2016), who believe that one of the focuses must be on social issues and how to prepare the workforce in the new industrial age.

When analyzing all the aforementioned studies, it is noted that it is not possible to work with Industry 4.0 technologies isolated. It is necessary to consider the managerial and people management aspects for all parties to evolve. Organizations need to have clear goals and draw a panorama of insertion and growth in the face of Industry 4.0 that is viable. In addition, the technologies are not created or operated alone, requiring competent personnel to carry out the tasks.

Finally, it is emphasized that there are many doubts about labor relations in this new industrial era and what skills are needed for new jobs. Automation will not diminish human interaction or create environments without employees; but it will significantly change the skill requirements of those involved. This can generate another high cost: in addition to the high price for adopting new technologies, they do not work and do not analyze data without human supervision. It is essential to look for ways to train personnel for the new reality. It must be emphasized that this can reduce the attractiveness of implanting Industry 4.0 in manufacturing 
companies in developing economies, mainly due to characteristics such as financial difficulties and low education levels (TORTORELLA; FETTERMAN, 2018).

\subsection{Learning Factories - definitions, technologies e didactic strategies}

The paradigm shift in the Industry 4.0 work will be successful if it includes, in addition to the technologies involved on the shop floor, the training approaches needed to support the continued development of communication, logic, and creativity skills. An operator's job in the face of Industry 4.0 will be qualitatively enriched and flexible and will require new skills to master digital technology. Future factories must support current workers in learning new skills while looking for new workers who are already familiar with digital solutions (KAASINEN et al., 2020).

This whole discussion about the training for technologies gains more relevance when it comes to students of engineering and other exact sciences. Sackey et al. (2017) reinforce the need to reform the courses curricula, guiding efforts to the most relevant elements. Students need to be prepared and enabled for the new functionalities, maintaining a constant vision of problem-solving.

It is worth reinforcing some points mentioned by Abele et al. (2017), in which manufacturing education and training have not kept pace with advances in technology or the demands of the labor market. Current practice is deficient in providing manufacturing employees with continuous engineering skills and solid educational and multidisciplinary training. In fact, traditional teaching methods show limited effectiveness in developing employee and student skills for new manufacturing environments. Also, the lack of social skills has been widely recognized by employers as a gap that needs to be addressed as soon as possible.

For Abele et al. (2017), the collaboration between academia and industry is crucial. Producing knowledge through research, spreading knowledge through education, and using and applying knowledge through innovation (the "knowledge triangle") is the appropriate approach. The authors reinforce that universities and industrial training facilities are faced with the challenge of identifying future job profiles and related competence requirements and need to adapt their teaching concepts and methods. Innovative learning environments must be able to respond to the challenges mentioned in an interdisciplinary way. In recent years, 
Learning Factories as environments close to the education and research sector have proven to be an effective concept for meeting these challenges.

It is important to understand where this learning factory concept came from. In 1994, the National Science Foundation (NSF) in the United States gave Penn State University grants to develop an apprenticeship factory. That was when the term "Learning Factory" was coined. It referred to practical interdisciplinary engineering projects with strong links and interactions with the industrial sector. A $2000 \mathrm{~m}^{2}$ facility equipped with machines, materials, and tools has been established and used to support hundreds of industry-sponsored projects since 1995 . This initial model of learning factories emphasizes the practical experience gained from applying the knowledge learned in engineering to solve problems in industry and design products to meet identified needs (LAMANCUSA et al., 2008).

Therefore, it is understood that Learning Factory is a realistic model of a production environment that offers students the opportunity to implement improvements in the process and see the results immediately. Its main objective is to bring the real world into the educational environment, providing students practical experience in real-life projects (SACKEY et al., 2017).

Learning Factories, therefore, have technological, business, and people management objectives to be met. According to Abele et al. (2019), the purpose is to contribute significantly to the continuous supply of competent professionals and to the constant updating and modernization of intellectual capital in the industry. Besides, LFs must contribute to research and transfer of innovation or business creation. The authors have identified in the literature some benefits that are difficult to achieve in other learning approaches: improving the quality of education and training in general; creation of possibilities for research, innovation, and technology transfer; development of soft skills and interdisciplinary skills; strengthening work attitude and philosophy; motivation to learn and motivation and confidence to apply; overcome the problems of traditional teaching methods.

Learning in a LF can be done through undergraduate courses, academic research, industry training, etc. There are also objectives for demonstrating technologies and transferring them to the industry; promoting an environment for experimenting with production models to be reproduced in the industrial context (TISCH et al., 2016).

Regarding the didactic strategy of the Learning Factories, most use active learning: the constant participation of those involved is encouraged through tests of their own ideas, critical 
analysis of the results obtained, and, if possible, sharing of the learning. Knowledge is developed from practical experiences and the solution of problems faced by manufacturing firms (ABELE et al., 2019).

There are two important perspectives when it comes to projects developed in learning factories, outlined in Figure 1.

Figure 1 - The use of Learning Factories in autonomous projects or industry-partnered projects

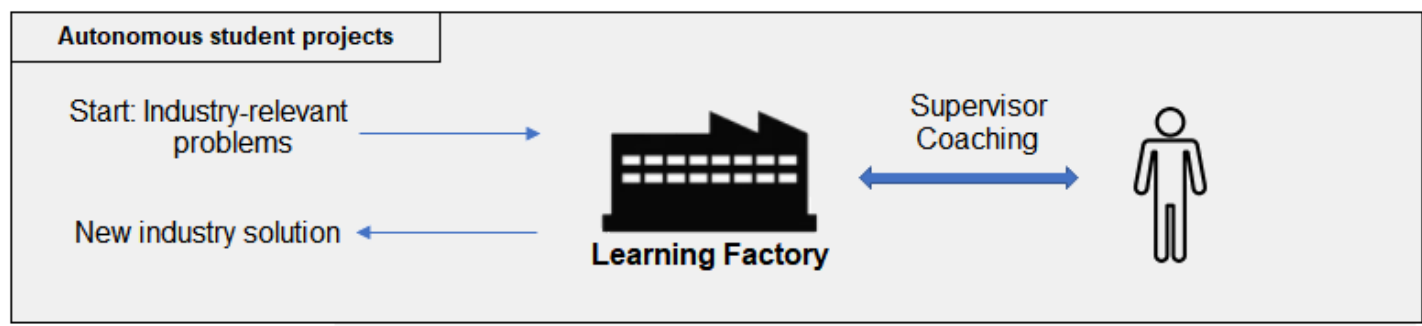

Industry-partnered student projects

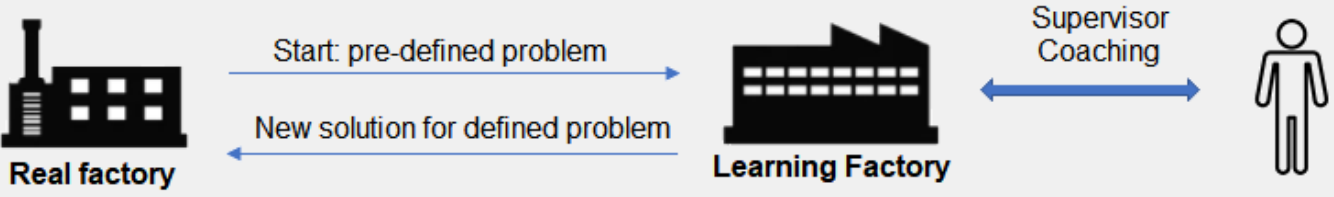

Source: Adapted from Abele et al. (2019).

Projects, in general, can last for weeks or even months. In the case of autonomous projects, students, individually or in groups, work to find technical or organizational solutions to predefined requirements or problematic situations. It is usually based on research questions identified by the students themselves. As a rule, the process of finding solutions for students is open to new creative solutions and is not restricted to a certain anticipated path. In some cases, students develop projects in partnership with industries. In these situations, students are most often trained by both the laboratory team and the partner organization members. The projects seek to group students from different areas of study. (ABELE et al., 2019)

With the advent of Industry 4.0, these learning environments started to gain more relevance. Kaasinen et al. (2020) believe that LF, by adopting an action-oriented approach, allows its participants to acquire competencies through structured self-learning processes in a production technological environment. Thus, the Learning Factories integrate different 
teaching methods in order to bring the teaching-learning processes closer to real industrial problems.

Manufacturing training should support the transition from current work to future knowledge work. Learning Factories integrate the learning and work environments and, thus, create realistic and relevant learning experiences, meeting the objectives of Industry 4.0 identified in the previous subsection. The interactive involvement and the participants' actions facilitate the development of competencies through structured self-learning processes, both in learning to solve known problems and in the learning of problem-solving processes (KAASINEN et al., 2020).

According to Abele et al. (2019), planning and simulation activities are very relevant in these learning environments and may include factory layout, simultaneous engineering, virtual reality, ergonomic evaluation, etc. The use of computers and the integration of Information Technologies and tools for analyzing the data collected are fundamental to the success of the laboratory. Digital activities can also be incorporated when offering visual software infrastructure and human interfaces to allow prototyping and digital models.

Different software tools are available on the market, and these are important for the training of students. The use of 3D printing and visualization programs are important for students' critical development, as well as the use of simulation programs. Also, the presence of information systems helps to foster the process of teaching and developing technologies. Some examples of systems are Enterprise Resource Planning (ERP), responsible for planning the company's resources, Manufacturing Execution Systems (MES), which manages production activities, Customer Relationship Management (CRM), which manages the relationship with the customer and Product Lifecycle Management (PLM), responsible for managing product data (TISCH et al., 2016; ABELE et al., 2019).

$\mathrm{Xu}, \mathrm{Xu}$ and Li (2018) showed in their study that IT has become dominant in industrial electronics, especially when considering the changes in the time spent by an engineer in the creation of control systems. Thus, it can be considered that the technologies mentioned here need to be treated in a didactic way so that those involved understand their potential. Learning Factories can adopt a diverse and updated range of IT to promote education. Additionally, Abele et al. (2017) believe that learning factories should be more closely linked to innovations, aiming at the generation of new prototypes, product/production technologies, and production processes. In order to further develop the possibilities of learning factories, 
business partners should always continue to share their ideas on networks to stimulate education, training, and research.

An example of a successful learning factory is the ESB Logistics Learning Factory, from the University of Reutlingen, Germany, dedicated to studying various logistical aspects of an industry. The available infrastructure is capable of storing, assembling, packaging, and organizing the shipment of recreational scooters. The product was selected due to its modularity, high variance, and reuse, where after a successful production, students can take a test. The training programs are designed for different target groups: for undergraduate students, LF is used to provide skills in essential tools and techniques in logistics and lasts from one to two days. In contrast, at the master's level, extensive projects are carried out involving groups of students, usually for up to fifteen weeks. Embracing product engineering problems are discussed, involving ideation and design, prototyping and testing phases, making use of the entire laboratory infrastructure (ABELE et al., 2019).

Another example of a successful Learning Factory is Die Lernfabrik, from the Technical University of Braunschweig, Germany. This LF's focus is to develop research and training in the areas of energy efficiency and sustainable cyber-physical systems. The factory consists of a real functional modular production system in a process chain from additive manufacturing to product assembly and scrap recycling. The research is carried out mainly by laboratory employees and doctoral students in cooperation with colleagues in collaborative projects with the industry. In terms of training, on the other hand, there are more solid structures for both staff and thematic guidance (ABELE et al., 2019).

Despite all the benefits pointed out, few studies report how to build an LF and what is the ideal IT architecture. This is in line with Sackey et al. (2017). These authors indicate that the seminal literature on Industry 4.0 does not seem to indicate that critical issues explicitly related to the Learning Factories infrastructure are being addressed. Although a relatively recent phenomenon, Learning Factories are increasingly being used as an effective platform of knowledge and competence for education, training, and research in industry and academia, where many of them have emerged around the world in the past decade.

Thus, it is verified the relevance of studying how a Learning Factory is constituted, the architecture of Information Technologies necessary for an adequate qualification, and what is its role in maintaining employability in the face of a new industrial era. 


\section{METHODOLOGICAL PROCEDURES}

This work is characterized as qualitative research. According to Gephart (2004), qualitative research is multimodal research that uses an interpretive and naturalistic approach to the proposed subject. Besides, it emphasizes the qualities of the entities - the occurring processes and their meanings. For the author, qualitative researchers also seek to explain research observations, providing well-substantiated conceptual insights that reveal how broad concepts and theories operate in particular cases.

Among the various types of qualitative research, this paper fits as a Case Study. According to Yin (2015), the case study is an empirical investigation that investigates a contemporary phenomenon in-depth and in its real-life context, especially when the limits between the phenomenon and the context are not clearly evident. Eisenhardt (1989) complements the definition by pointing out that the case study is a research strategy that focuses on understanding the dynamics present in unique environments. The studies can involve single or multiple cases and several analysis levels and generally combine data collection methods, such as documentation, interviews, questionnaires, and observations.

For conducting this Case Study, the steps proposed by Yin (2015) were followed, as shown in Figure 2.

Figure 2 - Case Study conduction steps

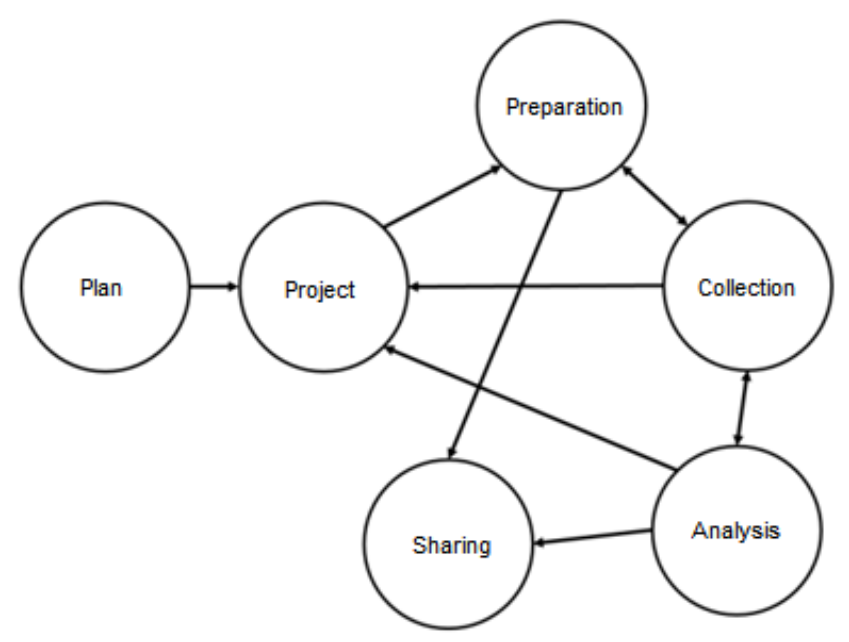

Source: Yin (2015). 
The Plan stage consists of identifying the problem and formulating research questions already presented in previous chapters. In the next stage, Preparation, it is relevant to identify the unit of analysis and type of study (holistic or integrated). This research is a single case study with a holistic approach (a single unit of analysis), guiding efforts towards studying a Learning Factory of a state university in Brazil. The interview script and other aspects necessary for the researcher's performance were determined at this stage.

Three semi-structured interviews were conducted with the laboratory coordinator and with interns and researchers regarding the Collection stage. According to Bryman and Bell (2015), semi-structured interviews employ a list of topics or some important questions to be asked during the interview. However, the use of a script can vary between the interviews, and it is up to the researcher to conduct them in order to extract the necessary information. In this case, the same script was applied to all interviews, as detailed in Annex 1. The script served to understand which technologies are present at Fábrica do Futuro, who operates them, which didactic activities have already been carried out in the laboratory, which are the stakeholders' expectations, among other aspects.

The sources that based the interview script were Abele et al. (2019), Tisch et al. (2016), and Lamancusa et al. (2008). In these works, there is a concern to understand the objectives and technologies to use in Learning Factories, the importance of having external partnerships and alignment of expectations between those involved, and the hypothesis that the integration between different LFs may further increase the benefits offered to students.

The initial contact with the interviewees was made by e-mail, explaining the research context. In addition to the interviews, secondary data sources served to increase the confidence of the study. For Eisenhardt (1989), the triangulation possible by various data collection methods provides a stronger foundation for constructions and hypotheses. As secondary sources, information extracted from the official YouTube channel and the official website, documents provided by those responsible for the laboratory, and participation in weekly follow-up meetings, where students and technology partners are present, were used.

All sources (primary and secondary) helped map Fábrica do Futuro and understand how the didactic activities already carried out allowed the development of technological and managerial skills.

Regarding the moment of data collection, the interviews were conducted by videoconference, given the situation of the Covid-19 pandemic experienced at the time of the 
study. The interviews were recorded and later transcribed, following the recommendations of Eisenhardt (1989) to do the transcriptions within 24 hours after the interviews. Then, in the Analysis stage, the data were analyzed and compared with the literature to verify how the IT architecture takes place and how important it is to train industry professionals.

Finally, it is worth discussing quality criteria in qualitative research. Eisenhardt and Graebner (2007) reinforce that a careful justification of the theories and validation with literature is necessary. The researcher must provide rich evidence in tables and appendices, base his sample theoretically and conduct the interviews in order to limit bias on the informants' part.

As Saunders et al. (2016), it is important to maintain reliability throughout the research. The authors present some threats to reliability:

- Participant error: refers to any factor that changes the way participants act. For example, a participant is in a hurry to answer a question. In this research, this aspect was eliminated by scheduling a sufficient time of 45 minutes to conduct the interview, with the interviewees' agreement.

- Search error: refers to any factor that alters the researcher's interpretation. For example, the researcher may be insufficiently prepared and, therefore, misunderstand the interviewee's subtle meanings. This was minimized in this research because the literature review brought an understanding of several concepts that guided the case study's conduct.

- Researcher bias: refers to any factors that induce bias in the record of the researcher's responses. For example, the researcher allows opinions and subjectivities to appear in the analyzes. In the case of this research, the record of all interviews was carefully made. All analyzes and impressions were recorded and organized, in addition to previous researcher training in conducting interviews.

\section{CASE STUDY: Fábrica do futuro}

The present study focuses on the case of a Learning Factory from a Brazilian state university, called Fábrica do Futuro. To understand its technological architecture and its 
relevance in the face of Industry 4.0, it is necessary first to understand the purpose of the laboratory, its origin, and operation.

The Fábrica do Futuro project started in 2016, and its proposal is to simulate, in a simplified way, a modern manufacturing environment composed of various Industry 4.0 technologies. Throughout the laboratory, there are technology demonstrators, which showcase the main technological innovations present for the assembly of customized products. The defined objective is to demonstrate the technologies applied to Industry 4.0, disseminating this knowledge to industry and academia. In this way, the environment works as a test platform in which scholars, students, and researchers, working closely with the associated companies, can learn and apply the technologies and provide training on Industry 4.0 and its enabling technologies for companies and executives.

The product made in this Learning Factory is a skateboard. This is a product that can be easily assembled by everyone who participates in practical activities to learn how current technology can be applied. It can be assembled and disassembled several times and, therefore, does not require raw material to be supplied continuously for the Learning Factory operation. The environment has 40 sets of skateboards (40 shapes, 80 trucks, 160 wheels, etc.), which can be customized in several ways: (i) diversify the colors of the wheels; (ii) choose the torque of the skateboard truck, through a minimum and maximum limit that makes the shock absorber rigid or soft; (iii) the presence or absence of rails, which can facilitate maneuvers; and (iv) the presence or absence of a connectivity box, which makes the product intelligent with the collection of information, such as the distance covered by the skateboard. The result is a "connected skateboard", whose present technologies show the product's real-time performance.

The skateboard's entire production goes through four different workstations, optimized based on the Lean Manufacturing philosophy, with manual production at all stages. Respondents claim that there is an intention to automate the process in the future. However, this would not represent most Brazilian industries' reality. Figure 3 shows the main components of the skateboard produced. 
Figure 3 - Representation of the skateboard produced

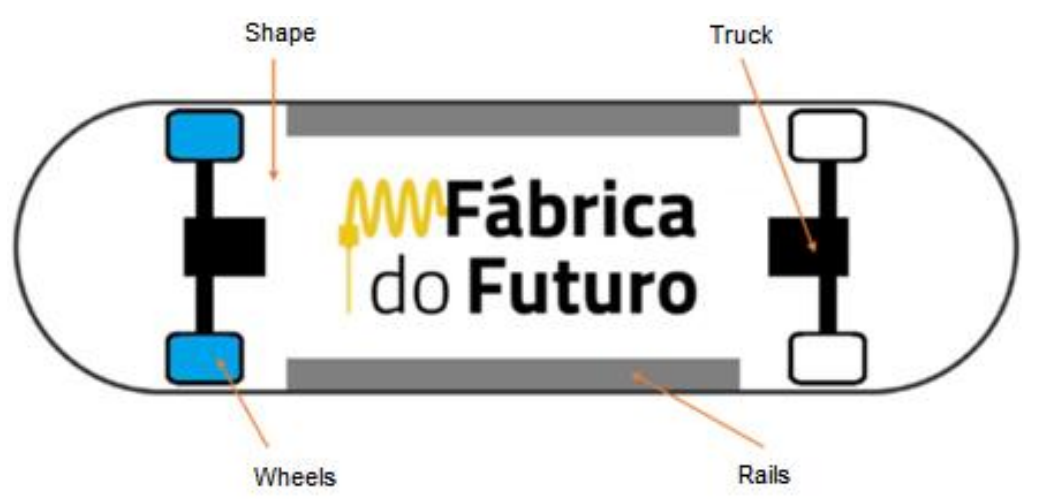

Source: Fábrica do Futuro (2020).

Throughout the production of the skateboard, different technology demonstrators are applied. Table 4 summarizes the demonstrators used in the production line.

Table 4 - Fábrica do Futuro technology demonstrators used in skateboard production

\begin{tabular}{|c|c|}
\hline Demonstrator & Function \\
\hline Customized assembly & $\begin{array}{l}\text { It starts in a product configurator in which the "customer", when ordering } \\
\text { the skateboard, chooses the color of the wheels, both front, and rear, with } \\
\text { connectivity box and rails as options. There is also the possibility to } \\
\text { choose the torque of the trucks. The production order is sent to the } \\
\text { production line workstations. }\end{array}$ \\
\hline $\begin{array}{l}\text { Quality Control } \\
\text { Computational Vision }\end{array}$ & $\begin{array}{l}\text { Through an ESOS intelligent industrial camera positioned on the second } \\
\text { assembly bench, it is possible to monitor whether the joining of wheels to } \\
\text { the trucks is being done correctly in accordance with the production order } \\
\text { generated by the "customer". If not, the operator receives feedback from } \\
\text { the system and corrects the error in the assembly. }\end{array}$ \\
\hline Customized manufacturing & $\begin{array}{l}\text { Through } 3 \mathrm{D} \text { printers, some low-volume skateboard options are produced. } \\
\text { Both the connectivity box and the rails can be 3D-printed on several } \\
\text { different types and colors of polymers. }\end{array}$ \\
\hline Distributed Manufacturing & $\begin{array}{l}\text { The 3D printers present in Fábrica do Futuro have the possibility of remote } \\
\text { monitoring because they are connected to the production line through the } \\
\text { Internet. The connectivity allows process monitoring in addition to } \\
\text { following the entire process with a camera positioned inside the machine. }\end{array}$ \\
\hline Connected Product & $\begin{array}{l}\text { When the customer chooses to have the connectivity box present on the } \\
\text { skateboard, a small box with an electronic IoT system is installed at the } \\
\text { bottom of the shape. This electronic system monitors the speed at which } \\
\text { the skateboard moves. A sensor identifies the skate's current position in } \\
\text { space and presents the 3D spatial position on a screen. }\end{array}$ \\
\hline Product Lifecycle Management & $\begin{array}{l}\text { Digital Twin's use allows the product to be analyzed in real-time, } \\
\text { collecting various information and analyzing it historically to better } \\
\text { understand its use. }\end{array}$ \\
\hline
\end{tabular}

Source: Fábrica do Futuro (2020). 
The laboratory has also adopted other technologies that do not directly comprise skateboards' production but help bring new views on Industry 4.0. One of them is the radio frequency technology (RFID), through tags and reader, which will soon identify the positioning of the tools used in the production line and manage inventory. A Digital Twin project is being developed, which aims to collect product data in real time on distance, speed, and weight, among others.

The most recent project that is about to integrate the production line is the implementation of an automatic sorting belt. This equipment separates the wheels according to their color in the appropriate boxes. Therefore, computer vision, automation, and cloud computing solutions were developed and integrated. Figure 4 shows this running machine.

Figure 4 - Automated sorting machine at the Fábrica do Futuro
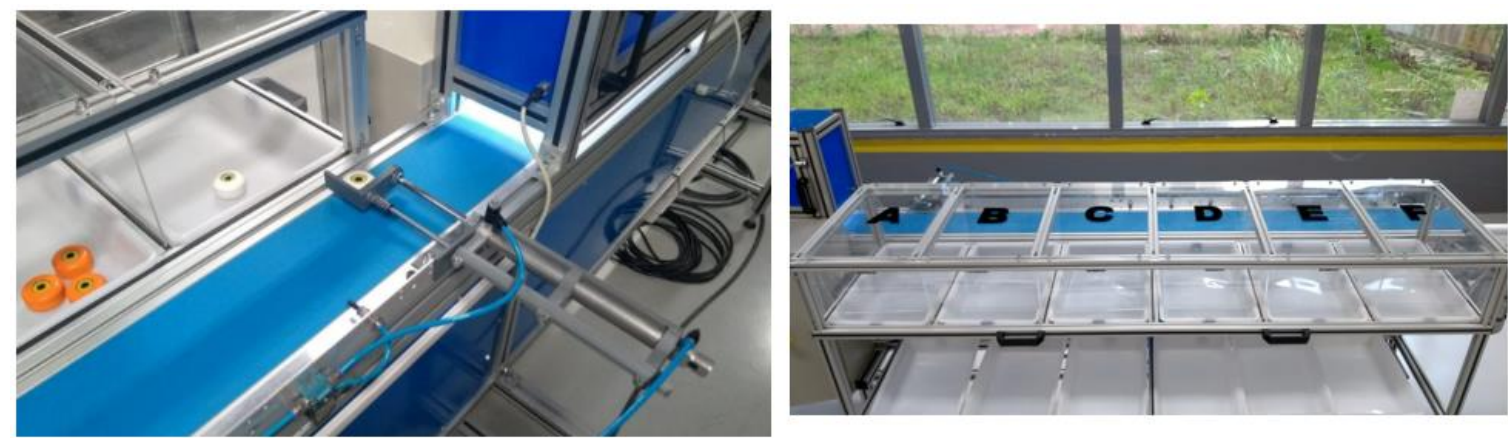

Source: The authors (2020).

Since the implantation of Fábrica do Futuro, several educational applications have been carried out. Until the end of 2020, the laboratory was used by seven courses from Engineering and Design programs, such as Ergonomics, Product and Process Development, Introduction to Electrical Engineering, among others. Students were invited to check opportunities for improvement in furniture and other ergonomic aspects in the Ergonomics course, develop team projects, and present the result to the whole class. In the case of Production Planning and Control's discipline, students performed the entire process of assembling and replenishing stock, being inserted into a real production process, and recommending improvements (Figure 5). In all cases, active learning is encouraged, as discussed by Abele et al. (2019). 
Figure 5 - Didactic activity taught at Fábrica do Futuro

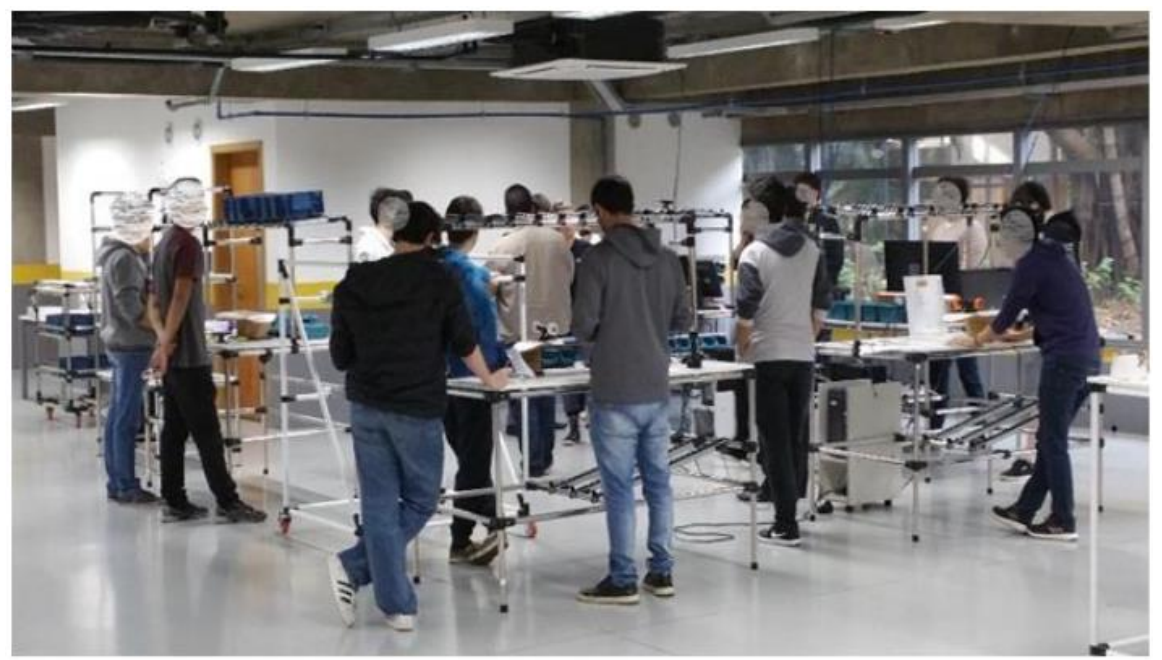

Source: Fábrica do Futuro (2020).

In addition to the aforementioned courses, master's and doctoral students carried out their research using the LF's infrastructure, covering topics such as Digital Twin, Additive Manufacturing, etc. The graduate students were able to develop their projects with the support of scholars and even the laboratory's technology partners. Thus, Fábrica do Futuro offers an adequate infrastructure for technological projects and encourages teaching-learning approaches that develop diverse skills. It is important to note that technologies and systems are available through solid partnerships with technology suppliers (hardware, software, maintenance, and consulting services). Some educational software licenses were granted to the laboratory.

After this explanation, along with the other information collected by the various means of data collection, it was possible to identify and detail the main technologies that make part at Fábrica do Futuro and the main skills developed, which will be discussed in the next section.

\section{RESULTS}

Throughout Fábrica do Futuro, Industry 4.0 technologies are applied in the skateboard production line and other stations for additional projects. Table 5 seeks to summarize the main technologies applied in the laboratory. 
Table 5 - Technologies and systems present at Fábrica do Futuro

\begin{tabular}{ll}
\hline \multicolumn{1}{c}{ Technology/system } & \multicolumn{1}{c}{ Function at the laboratory } \\
\hline $\begin{array}{l}\text { Enterprise Resource Planning } \\
\text { (ERP) }\end{array}$ & $\begin{array}{l}\text { Controls all information, such as resources, processes, quantities and other } \\
\text { types of data. }\end{array}$ \\
\hline $\begin{array}{l}\text { Manufacturing Execution } \\
\text { Systems (MES) }\end{array}$ & Controls production steps in real-time. \\
\hline $\begin{array}{l}\text { Product Lifecycle Management } \\
\text { (PLM) }\end{array}$ & Manages the product-related data in the product design phase. \\
\hline Computational Vision & $\begin{array}{l}\text { Assists in quality management, checking if the customer's wheel color } \\
\text { requirements are being met. Based on a machine learning algorithm. Recently, } \\
\text { a new camera started to assist in the wheel's automatic sorting in the } \\
\text { skateboard's disassembling process. }\end{array}$ \\
\hline QR Code & $\begin{array}{l}\text { Serves to identify parts and control the production of the skateboard as it } \\
\text { progresses through the workstations. }\end{array}$ \\
\hline RFID & $\begin{array}{l}\text { Not yet in use, but there are already projects for controlling tools and } \\
\text { inventory management. }\end{array}$ \\
\hline 3D printing & $\begin{array}{l}\text { Responsible for the production of rails. The machines are interconnected with } \\
\text { other IT systems in the environment. Different polymers can be used for } \\
\text { resistance testing and other aspects. }\end{array}$ \\
\hline Digital Twin & $\begin{array}{l}\text { Supports product simulation in a virtual environment in order to collect } \\
\text { information in real-time from the skateboards that have the connectivity box, } \\
\text { such as distance covered, average and maximum speed reached, etc. }\end{array}$ \\
\hline Computer-aided design (CAD) & $\begin{array}{l}\text { Applied to model and design the skateboard parts that are produced by 3D } \\
\text { printing. }\end{array}$ \\
\hline Cloud & $\begin{array}{l}\text { Stores information in the cloud. The system servers are also in the cloud, } \\
\text { allowing remote access. }\end{array}$ \\
\hline Automated torque wrench & Equipment which uses the customer's request to determine the skate's torque. \\
\hline Source: Prepared by the authors (2020).
\end{tabular}

The skateboard's production begins with the customer's order and the customization chosen in an ERP system interface. The order is created and then sent to the first workstation via MES, providing instructions for assembly. Through the production line, tag identification is used to identify each product. At each bench, information is collected and sent in real-time to the MES. At the second workstation, a camera collects images and uses computational vision and machine learning to check if the wheel positions and colors are correct according to the individual production order. At the third workstation, custom torque is applied to the truck. At the fourth workstation, options (connectivity box and rails) can be applied, if selected by the customer.

When the customer requests options, the laboratory's IT architecture itself will send the request to one of the available $3 \mathrm{D}$ printers so that the part can already be produced. Although the information systems are from different suppliers, it will be possible to relate information between them, allowing the entire process to be integrated. This integration was under implementation during the data gathering by this research. 
All of this brings up a critical aspect of Industry 4.0: the integration of technologies and processes. The production line was built in a way that systems exchange and store information, accelerating and optimizing the entire process. Also, there is a digital value chain that reinforces the importance of these technologies. This concept is widely disseminated among the participants in this Learning Factory activities, who realize that it is increasingly necessary to seek integration in organizations. Integration brings several benefits:

- The order information is stored in different systems (e.g., ERP and MES), generating a reliable database that allows forecasts, simulations, and production organization. Product configuration information gathered at the ERP Product Configurator is integrated into the MES for production execution management.

- In case of faults detected by computational vision, the process is not continued in the MES system, preventing the product from continuing on the line with errors. Besides, computational vision speeds up and optimizes the process of disassembling the skateboard, preventing parts from being returned to incorrect locations.

It is worth emphasizing that the available technologies can be used for projects outside the production of skateboards. Undergraduate and graduate students develop projects that use one or more of the LF's technologies. Some Engineering courses use the laboratory to develop knowledge about production lines, production scheduling, times, and methods, and end up working indirectly on Industry 4.0 technologies and their relevance in the market today.

There is a student project to start inventory control with the use of RFID tags. The idea is to simulate a modern warehouse in which antennas collect inputs and outputs of materials in real-time, automatically updating the laboratory's inventory. Here again, systems integration is critical for the application to work.

Recently, some students were challenged to prepare face shields for medical teams due to the Covid-19 pandemic, using CAD and 3D printers. Much of the work takes place remotely, as the systems have servers in the cloud and only people authorized to enter the laboratory do the verification of the parts. In the pandemic context, one of the technology partners developed software that uses computational vision to identify whether an employee or student is wearing a mask correctly. If not, an alert is issued when it enters the laboratory.

In one of the interviews, it was mentioned that there is a product development discipline in which students form teams and are challenged to develop proofs of concept for solving real problems, provided through partnerships with companies using Industry 4.0 
technologies. Fábrica do Futuro has a fundamental role in providing equipment and support in the construction of prototypes, developing knowledge about modern technologies and software, as well as creativity to solve the problem. The last time this course was offered, the teams developed software to monitor machines, execute quality control checks, and track tools on the factory floor.

In addition to the students having developed knowledge about Industry 4.0, they needed to link the available technologies with programming languages, such as Python and Java Script (and their derivatives such as Node.js and others), so that the technologies can be developed according to solutions requirements. This brings up another important aspect of the transition to Industry 4.0: in order to meet the company's needs, it may often be necessary to use advanced programming to deploy the technologies according to the company's specific objectives. It is possible to exemplify using one of the course groups' ideas: the computational vision camera needed to identify product manufacturing flaws. In order to identify the failures with the greatest possible confidence, the prototype had to rely on software and the respective use of programming to analyze color and shadow matrices so that the failure analysis was carried out correctly.

In addition to offering software and other tools, the laboratory's technology partners assist in system management and offer maintenance. As there are no specialized IT staff available full time, partners must act promptly in case of technical problems. The fact that the servers are in the cloud facilitates problems' resolutions, as visits to the laboratory are not necessary repairing. This highlights another relevant factor in Industry 4.0: cloud services allow for new ways of working and faster problem-solving.

The corporate partners are interested in this Learning Factory as there is a mutual exchange of information and learning. On the one hand, companies offer the latest solutions available in the market and bring students closer to a real professional environment. On the other hand, organizations can follow the development of innovative projects and have access to these technologies first, bringing challenges to be discussed in an environment conducive to tests. Therefore, the companies themselves can take advantage of the LF infrastructure to carry out tests and developments of their products.

Based on all the above and on the collected materials, it is possible to summarize how each of the technology demonstrators presented in Table 6 is conceptually and practically presented to students who use Fábrica do Futuro. Table 6 can serve as a general model for the 
construction of the IT architecture of an industrial simulation environment, according to the objectives of this study.

Table 6 - Technologies needed to put demonstrators into practice

\begin{tabular}{cc}
\hline Demonstrator & Essential Technologies/systems \\
\hline & ERP \\
Customized Assembly & ERP Product configurator \\
& MES \\
& QR Code \\
& 3D printing \\
\hline \multirow{3}{*}{ Quality Control - Computational Vision } & MES \\
& Computational Vision cameras \\
& Machine Learning \\
\hline \multirow{2}{*}{ Customized Manufacturing } & ERP \\
& MES \\
\hline Distributed Manufacturing & 3D printing \\
\hline Connected Product & 3D printing \\
\hline & IoT \\
\hline & ERP \\
Product Lifecycle Management & MES \\
& PLM \\
& CAD \\
\hline \multirow{2}{*}{ Inventory management (still under development) } & ERP \\
\hline
\end{tabular}

Source: Prepared by the authors (2020).

It can be seen in this table that the available technologies and the objectives intended in this study are aligned with the literature, especially the provisions by $\mathrm{Lu}$ (2017) and Celaschi (2017). Therefore, it can be said that Fábrica do Futuro helps to train specialized labor in undergraduate and graduate courses, in addition to disseminating knowledge to the industry. Several works are developed together with the corporate partners, which allows for an active exchange of information and development of projects aimed at Industry 4.0.

In view of the various technologies and their integration, it is possible to act in several aspects related to training: to conceive a vision of systems integration, develop specific knowledge for a specific tool or set of tools, and/or stimulate soft skills. Courses and training can be created considering the development of skills such as oral communication, analytical reasoning, creativity, teamwork, among others. This form of training, which has already been taught at Fábrica do Futuro through courses and other projects, develops a full range of skills for industrial performance, which shows that Learning Factories are able to meet the diverse needs of modern organizations. Therefore, the learning factories act against the shortage of 
specialized labor by offering adequate infrastructure, partnerships with industries, and encouraging the active learning of students through interdisciplinary projects.

Figure 6 summarizes the main skills developed in projects of Fábrica do Futuro, which are in line with the literature.

Figure 6 - Main competences developed in Fábrica do Futuro projects

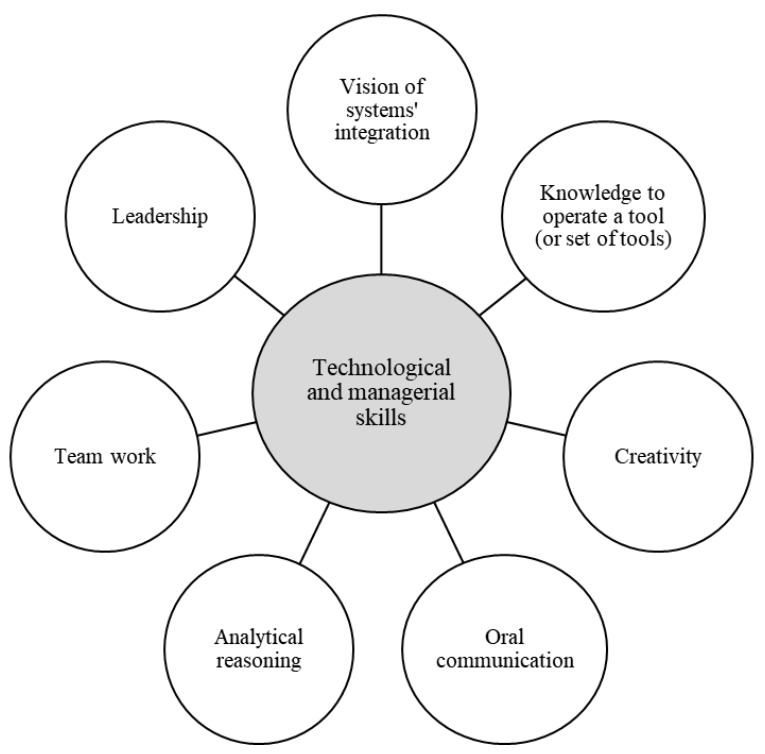

Source: Prepared by the authors (2020).

Given all the above, it appears that the Factory of the Future has the focus of demonstrating a more realistic industrial environment, considering aspects of lean and quality in production. These resources are available for use in all courses at the university, upon prior scheduling of classes, as well as for the development of research at the most diverse levels (scientific initiation, master's, doctorate, or post-doctorate). As has already been explained, over the years, several undergraduate disciplines and graduate students have developed activities in this Learning Factory, using both the production line for visualization of technologies and individual technologies for particular purposes, such as the development of tests of concept for product designs.

It is worth emphasizing that the focus is not only on those involved in universities, as there is a plan to offer workshops to companies to reflect on what technologies can be applied to their organization and create a roadmap for implementation. Training courses open to the public are on the horizon of actions of this Learning Factory. Therefore, training takes place at 
the most different levels of education and with different audiences through activities that can be adapted according to the knowledge that one wishes to acquire.

\section{FINAL REMARKS}

This study aimed to analyze what are the most relevant technologies in Learning Factories, how these technologies are integrated, and how this environment works in the face of a specialized labor shortage. Through the case study of Fábrica do Futuro, it was possible to infer an example of IT architecture for these teaching environments and show the diverse range of possibilities for practical studies that can occur in this laboratory. It is possible to promote training that develops a wide range of competencies to work in the industry.

Regarding the first proposed research question (How is the IT architecture of Learning Factories environments structured?), Tables 5 and 6 provide an overview of the most important technologies and which ones should be used for the desired demonstration. This shows that technologies integrate in different ways and satisfy different needs. Exploring and improving the integration between various tools is one of the main objectives of Industry 4.0 and Fábrica do Futuro operates on this front, both in disciplines and in undergraduate and graduate projects, in partnership with technology suppliers.

Regarding the second research question (What aspects can be developed in a Learning Factory for industry professionals' technological education today?), Tables 5 and 6 show which technologies are most relevant at the moment, and Figure 6 summarizes the main skills that must be acquired by industry professionals. These skills are worked on at Fábrica do Futuro through interdisciplinary projects that stimulate student's active learning.

The greatest emphasis of this study should be given to the integration of technologies and systems and how it affects the entire production line. The operationalization of several tools that communicate and exchange information represents the situation that modern industry is currently experiencing. Professionals involved in solution integration need to have developed knowledge in more than one technology since the macro view of the process is fundamental for understanding what happens and allowing efficient data collection and analysis. This integration inherent to Industry 4.0 requires technological knowledge and communication, leadership, creativity, and problem-solving skills. Therefore, the training 
needs to involve technological aspects and complementary skills that will result in a higher professional performance in the field.

Another relevant point is that the design and maintenance of the environment require solid partnerships with technology suppliers, which provide access and support to systems currently available on the market. Only with the presence of sophisticated technologies that allow integration with the entire value chain a Learning Factory can train professionals for the new industrial reality. This does not necessarily represent a high investment: as already mentioned, partner companies also benefit from the use of these spaces and can test their products.

It appears, therefore, that the technologies available at Fábrica do Futuro have complementary objectives and stimulate various concepts. The teaching strategy that uses most of these available tools is the one that has the greatest chance of success in training for Industry 4.0, as it stimulates not only the technical knowledge but also the relationship of concepts and a broader vision for solving problems.

This work, therefore, aims to contribute to universities and research institutions that wish to implement this teaching approach, presenting and discussing a possible IT structure and the skills developed with it. It is worth emphasizing that this is a unique case study. Each institution must observe its particularities and the objectives it wishes to achieve with the implementation of an LF to determine better its IT architecture and which training strategies to adopt.

To further achieve this article's objectives, it would be ideal to compare it with other Learning Factories, even if in a theoretical way, to generalize a common IT architecture at a national or global level. However, the case studied brings various technologies from Industry 4.0 and allows to meet the objectives identified in the literature for these environments.

This research's field does not end with this study, and there is a research agenda that can be explored to deepen this area. A possibility that is not addressed in the literature is how Learning Factories can train people regarding Occupational Health and Safety (OHS) and how to adapt these laboratories to deal with safety issues. Another possibility is to analyze partnerships between Learning Factories, at a national or international level, to analyze how this exchange of knowledge and technologies can further strengthen the teaching-learning process for the new tools. Besides, direct monitoring of disciplines and projects carried out 
entirely in an LF can bring interesting insights into this environment's benefits and shortcomings.

\section{References}

ABELE, E; CHRYSSOLOURIS, G.; SIHN, W.; METTERNICH, J.; ELMARAGHY, H.; SELIGER, G.; SIVARD, G.; ELMARAGHY, W.; HUMMEL, V.; TISCH, M.; SEIFERMANN, F. Learning factories for future oriented research and education in manufacturing. CIRP Annals - Manufacturing Technology, v. 66, n. 2, p. 803-826, 2017.

ABELE, E.; METTERNICH, J.; TISCH, M. Learning Factories: Concepts, Guidelines, Best-Practice Examples. Ed. Springer Cham, Switzerland, 2019

ADAMSON, G.; WANG, L.; HOLM, M.; MOORE, P. Cloud manufacturing -a critical review of recent development and future trends. International Journal of Computer Integrated Manufacturing, v. 30, n. 4-5, p. 347-380, 2017.

BAENA, F.; GUARIN, A.; MORA, J.; SAUZA, J.; RETAT, S. Learning Factory: The Path to Industry 4.0. Procedia Manufacturing, v. 9, p. 73-80, 2017.

BAHETI, R.; GILL, H. Cyber-Physical Systems. The Impact of Control Technology, v. 12, p. 161-166, 2011.

BEIER, G; ULRICH, A.; NIEHOFF, S.; REIBIG, M.; HABICH, M. Industry 4.0: How it is defined from a socio-technical perspective and how much sustainability it includes - a literature review. Journal of Cleaner Production. v. 259, p.1-13, 2020.

BRYMAN, A.; BELL, E. Business Research Methods. Oxford University Press, 808p, 2015.

CELASCHI. F. Advanced design-driven approaches for an Industry 4.0 framework: The human-centred dimension of the digital industrial Revolution. Strategic Design Research Journal, v.10, n.2, p. 97-104, 2017

EISENHARDT, K. M. Building Theories from Case Study Research. Academy of Management Review, v. 14, n.4, p. 532-550, 1989

EISENHARDT, K. M.; GRAEBNER, M. E. Theory building from cases: Opportunities and challenges. Academy of Management Journal, v.50, n.1, 25-32, 2007.

FÁBRICA DO FUTURO. Site oficial do laboratório. Disponível em: <https://sites.usp.br/fabricadofuturo/> Acesso em 01/08/2020

FLEURY, M. T. L.; FLEURY, A. C. Construindo o conceito de competência. Revista de Administração Contemporânea, v. 5, n. SPE, p. 183-196, 2001. 
FRANK, A. G.; DALENOGARE, L. S.; AYALA, N. F. Industry 4.0 Technologies: implementation patterns in manufacturing companies. International Journal of Production Economics, v. 210, p.15-26, 2019

GEPHART, R. From the editors: Qualitative Research and the Academy of Management Journal. Academy of Management Journal, v.47, n.4, p. 454-462, 2004.

GUERREIRO, B. V.; LINS, R. G.; SUN, J.; SCHMITT, R. Definition of Smart Retrofitting: First Steps for a Company to Deploy Aspects of Industry 4.0. In: A. Hamrol et al. (eds.). Advances in Manufacturing. Springer International Publishing, p. 161-170, 2019

HERMANN, M.; PENTEK, T.; OTTO, B. Design Principles for Industrie 4.0 Scenarios. 49th Hawaii International Conference on System Sciences, p. 3928-3938, 2016.

KAASINEN, E. et al. Empowering and engaging industrial workers with Operator 4.0 solutions. Computers and Industrial Engineering, v.139, n. January 2019, 2020.

KAGERMANN, H.; WAHLSTER, W.; HELBIG, J. Recommendations for implementing the strategic initiative Industrie 4.0: final report of the Industrie 4.0. Working Group. 82p, 2013.

KAYA, İ.; ERDOGAN, M., KARASAN, A.; OZKAN, B. Creating a road map for industry 4.0 by using an integrated fuzzy multicriteria decision-making methodology. Soft Computing, 2020. https://doi.org/10.1007/s00500-020-05041-0

KONIECZEK, B.; RETHFELDT, M.; GOLATOWSKI, F.; TIMMERMANN, D. A distributed time server for the real-time extension of coap. In: 2016 IEEE 19th international symposium on real-time distributed computing (ISORC), p. 84-91, 2016.

LAMANCUSA, J.S., ZAYAS, J.L., SOYSTER, A.L., MORELL, L., JORGENSEN, J. The Learning Factory: Industry-Partnered Active Learning-2006 Bernard M. Gordon Prize Lecture. Journal of Engineering Education. v. 97, n.1, p. .5-11, 2008

LASI, H.; FETTKE, P.; KEMPER, H. G.; FELD, T.; HOFFMANN, M. Industry 4.0. Business \& information systems engineering, v. 6, n.4, p. 239-242, 2014.

LEE, J.; LAPIRA, E.; YANG, S.; KAO H. Predictive manufacturing system trends of next generation production systems. In: Proceedings of the 11th IFAC workshop on intelligent manufacturing systems, p. 150-156, 2013.

LU, Y. Industry 4.0: A survey on technologies, applications and open research issues. Journal of Industrial Information Integration, v. 6, p. 1-10, 2017.

MCKINSEY \& COMPANY. Industry 4.0 after the initial hype Where manufacturers are finding value and how they can best capture it. Available in: < https://www.mckinsey.com/ /media/mckinsey/business\%20functions/mckinsey\%20digital/ou r\%20insights/getting\%20the $\% 20$ most $\% 20$ out $\% 20$ of $\% 20$ industry\%204\%200/mckinsey_indust ry_40_2016.ashx> Access 28/08/2020. 
MINISTÉRIO DA EDUCAÇÃO E PESQUISA DA ALEMANHA. What is Industry 4.0.

2016. Available in: <https://www.plattform-

i40.de/I40/Navigation/EN/Industrie40/WhatIsIndustrie> Access: 03/08/2020

NAGY, J., OLÁH, J., ERDEI, E., MÁTÉ, D., \& POPP, J. The role and impact of industry 4.0 and the internet of things on the business strategy of the value chain-the case of hungary.

Sustainability Switzerland, v. 10, n. 10, p. 1-12, 2020

NAKAYAMA, R. S.; DE MESQUITA SPÍNOLA, M.; SILVA, J. R. Towards I4.0: A comprehensive analysis of evolution from I3.0. Computers and Industrial Engineering, v. 144, n. February 2019, p. 1-15, 2020.

OESTERREICH, T. D.; TEUTEBERG, F. Understanding the implications of digitisation and automation in the context of Industry 4.0: A triangulation approach and elements of a research agenda for the construction industry. Computers in Industry, v. 83, p. 121-139, 2016.

PEREIRA, A. C.; ROMERO, F. A review of the meanings and the implications of the Industry 4.0 concept. Procedia Manufacturing, v. 13, p. 1206-1214, 2017.

PICCAROZZI, M.; AQUILANI, B.; GATTI, C. Industry 4.0 in Management Studies: A Systematic Literature Review. Sustainability Journal, v.10, p. 21-38, 2018.

POSADA, J., TORO, C., BARANDIARAN, I., OYARZUN, D., STRICKER, D., PINTO, E., EISERT, P., DOLLNER, J.; VALLARINO, I. Visual Computing as a Key Enabling Technology for Industrie 4.0 and Industrial Internet. IEEE Computer Society. Appl., v. 35, n. 2, p.26-40, 2015.

RÜßMANN, M.; LORENZ, M.; GERBERT, P.; WALDNER, M.; JUSTUS, J.; ENGEL, P.; HARNISCH, M. Industry 4.0: The Future of Productivity and Growth in Manufacturing Industries. The Boston Consulting Group. 2015.

SABO, F. Industry 4.0 - a comparison of the status in Europe and the USA. Austrian Maschall Plan Foundation, 33p., 2015.

SACKEY, S. M.; BESTER, A.; ADAMS, D. Industry 4.0 learning factory didactic design parameters for industrial engineering education in South Africa. South African Journal of Industrial Engineering, v. 28, n. 1, p. 114-124, 2017.

SALERNO, M. S. Projeto de organizações integradas e flexíveis: processos, grupos e gestão democrática via espaços de comunicação-negociação. São Paulo: Editora Atlas, 1999.

SANDERS, A.; ELANGESWARAN, C.; WULFSBERG, J. Industry 4.0 implies lean manufacturing: research activities in industry 4.0 function as enablers for lean manufacturing.

Journal of Industrial Engineering and Management, v. 9, n. 3, p. 811-833, 2016.

SAUNDERS, M., LEWIS, P.; THORNHILL, A. Research methods for business students. 7. ed., Harlow: Pearson Education, 2016

SCHUH, G. Collaboration moves productivity to the next level. Procedia CIRP 17, p.3-8, 2014.

SCHWAB, K. The Fourth Industrial Revolution. In: Genebra: World Economic Forum, 2016. 
SIMA, V.; GHEORGHE, I. G.; SUBIC, J.; NANCU, D. Influences of the Industry 4.0 Revolution on the Human Capital Development and Consumer Behavior: A Systematic Review. Sustainability, v. 12, 4035, 2020. https://doi.org/10.3390/su12104035

STOCK, T., OBENAUS, M., KUNZ, S., KOHL, H. Industry 4.0 as enabler for a sustainable development: a qualitative assessment of its ecological and social potential. Process Safety Environmental Protection. v. 118, p. 254-267, 2018

SUNG, T. K. Industry 4.0: A Korea perspective. Technological Forecasting and Social Change, v. 132, p. 40-45, 2018.

TISCH, M.; HERTLE, C.; ABELE, E.; METTERNICH, J.; TENBERG, R. Learning factory design: a competency-oriented approach integrating three design levels. International Journal of Computer Integrated Manufacturing, v. 29, n. 12, p. 1355-1375, 2016.

TORTORELLA, G. L.; FETTERMANN, D. Implementation of industry 4.0 and lean production in brazilian manufacturing companies. International Journal of Production Research, v. 56, n.8, p. 2975-2987, 2018.

XU, L. Da; XU, E. L.; LI, L. Industry 4.0: State of the art and future trends. International Journal of Production Research, v. 56, n. 8, p. 2941-2962, 2018.

YIN, R. K. Estudo de caso: planejamento e métodos. 5. ed. Porto Alegre: Bookman, 2015.

ZANCUL, E. VIEIRA, H. Machine vision applications in a learning factory. Procedia Manufacturing, v. 45, p. 516-521, 2020. 


\section{ANNEX 1 - Interview script}

1) What is the Fábrica do Futuro and what is your role in it?

2) What are the technologies and software available in the laboratory?

3) How are these technologies integrated and who operates them?

4) Talk about some practical activities developed at Fábrica do Futuro.

5) What is the importance of an environment like Fábrica do Futuro for the IT training of those involved and participants?

6) What is the relevance of Fábrica do Futuro in view of Industry 4.0 reality?

7) What do the technology partners of Fábrica do Futuro expect from this laboratory?

8) Is there any contact and / or partnership with any other learning factory? Where was the inspiration for building this laboratory?

9) Comments and other opinions about the technologies of Fábrica do Futuro and their relevance to the scenario of Industry 4.0 today. 